\title{
Contemporary Fairy Tales: Narrating Women Academics Through Metaphors
}

\author{
Sofia Moratti ${ }^{*}$
}

Published: September 1, 2021

\begin{abstract}
This article contributes to the feminist literature that explores the vast landscape of metaphors on the professional experiences and identities of women academics found in scholarly works. In their now classic studies on the semantic content of these tropes, feminist scholars have identified one large cluster of metaphors that allude to structural barriers or natural phenomena (e.g., 'glass ceiling' and 'chilly climate'), criticised for overlooking human agency. This paper is novel in that identifies (and problematises) another ample cluster of shared meanings: 'tale and myth' metaphors drawing from fairy tales, legends, sagas, folklore, mythology and religious imagery. I argue that many such metaphors aim to capture the lower status of women academics (e.g., 'Cinderella'), and are characterised by: liminality, as they open up possible-worlds and untested social arrangements (e.g., 'Alice in Wonderland'); ambivalence, as they portray women as either monsters, or prodigies, or both (e.g., 'intellectual Frankenstein'); reductionism, in that they implicitly seek to subsume complex social phenomena under familiar fictional plots; and (relatedly) normativity, in that they create expectations as to the likely development of a situation and implicitly suggest a course of action. Particularly the latter two characteristics constitute significant limitations of 'tale and myth' metaphors: nonetheless, can there still be merit in their use? In the paper, I advance a suggestion.
\end{abstract}

Keywords: gender, discourse, higher education, organisations, metaphors

\section{INTRODUCTION. METAPHORS, MYTHS AND TALES}

Organisations are gendered (Kanter, 1977; Acker, 1990; Gherardi, 1995; Benschop and Dooreward, 1998; Benschop and Verloo, 2006; Kvande, 2007) and academia is no exception (Husu, 2000; Bagilhole and Goode, 2001; Van den Brink and Benschop, 2012; Thornton, 2013). The language we use reveals that. This paper is a meta-reflection problematising the literary and symbolic images, or metaphors, used in white papers, in the scholarly literature and the media to refer to the professional lives and experiences of women academics (Amery et al., 2015; Moratti, 2018). I situate my investigation within the gender, work and organisations scholarship discussing metaphors on women in organisations (Bendl and Schmidt, 2010; Smith et al., 2012; Kemp, 2016). The imagery we invoke brings in implicit meaning (Goatly, 2007; Zinken and Mulsolff, 2009) and conveys a particular interpretation of the nature of the professional hindrances that women encounter. The question has been discussed in the feminist literature with highly interdisciplinary and original approaches, following the 'linguistic turn' in feminist studies (Tolmach-Lakoff, 1973; Spender, 1980) and drawing on the seminal works by linguist George Lakoff (Women, Fire, and Dangerous Things, 1987) and business theorist Gareth Morgan (Images of Organizations, 1986). Feminist scholars have produced an impressive body of knowledge and the use of metaphors on women in work organisations is now an important topic in feminism, but surprisingly not (yet) a core one. Key texts such as the Oxford Handbook of Feminist Theory (2016) and the Oxford Handbook of Gender in Organizations (2014) do not include a dedicated chapter on metaphor use. Even more remarkably, the word 'metaphor' is not listed in the index of either handbook. The indexes go into a considerable level of detail and respectively include 'men's rights movement' and 'merit', the latter encompassing as many as nine sub-entries (Kumra et al., 2014; Disch and Hawkesworth, 2018). However, the investigation of metaphor use is fertile intellectual terrain affording exceptional opportunities for creative and methodologically original inquiry leading to theoretical insights. It is foundational to feminist 
organisational studies rather than a mere line of investigation (Leonard, 2002). As a scholarly topic, it remains as timely as ever.

In their meta-reflection on metaphor use, feminist scholars have discussed the semantic content of these figurative expressions and identified patterns of meaning. Contributions that have now become foundational to the study of metaphors on women academics have pointed out that many such tropes hint to rigid exclusionary structures or natural hazards and draw from the terminology of engineering and architecture and the natural world. These expressions fail to capture agency. They conceptualise women as passive and they cloud the responsibility of fellow academics in creating and maintaining gender inequity (Husu, 2001; Benschop and Brouns, 2003). Examples are 'black hole' and 'leaking pipeline', alluding to the large proportion of women academics whose careers end before reaching tenure. 'Glass ceiling', 'sticky floor' and 'slippery paths' symbolise insidious impediments to professional advancement. 'Glass cliff' means that women get access to leadership roles in higher education (such as Department Head) as these jobs 'decline in status', 'become more time-consuming and harder to combine with a successful scholarly career' and entail a higher 'risk of failure' and 'interpersonal conflict' (Peterson, 2014: 41). 'Chilly climate' describes the atmosphere of ostracism and the isolation that women academics can experience in their daily work environment. However, gender inequity is not about floors and ceilings: it is about people. Women academics are not water drops dripping from a broken pipe, nor particles disappearing into a region of spacetime: they are persons with plans, opinions and strategies. Unwelcoming attitudes towards women colleagues have nothing to do with the weather conditions. Rather than 'paths', people's behaviour can be 'slippery' particularly when their own privilege is threatened by the advancement of historically marginalised groups. In essence, contrary to what nature- and engineering-inspired metaphors on women in academia seem to suggest, we are not trapped in gendered structures and much can be done to achieve change, as pointed out by the scholars who first identified and problematised this particular cluster of figurative expressions (Husu, 2001).

The goal of this article is drawing attention to another major pattern in the vast landscape of metaphors on women and academia, one that has been there for a long time, but has so far not yet been adequately analysed in the literature. There is a large set of tropes that seem to draw directly from fairy tales and fantasy, legends and sagas, folklore, classical mythology and religious imagery. This is perhaps the largest cluster of metaphors on women academics, along with the above discussed expressions derived from the world of architecture, engineering and the natural world. This article offers a discussion of some 'myth and tale' metaphors and their conceptual implications, presenting original arguments. I contend that (1) 'myth and tale' metaphors aim to depict the unequal status of women in academia and are characterised by (2) liminality as they open up the possibility to move beyond a limited and familiar world and to imagine and explore alternative possible-worlds; (3) ambivalence in that they often conceptualise women as either monsters, or prodigies, or both, to capture their 'otherness' in traditionally mendominated professions; (4) reductionism, as they evoke a limited number of familiar fictional plots and assume that those can reflect the complexity of social reality; (5) normativity, in that they trigger expectations as to the likely outcome of a situation and dictate a proper course of action. The latter two features constitute a limitation of 'myth and tale' metaphors, that is almost as big as the limits that have already been pointed out for nature and engineering inspired metaphors. The article ends with considerations on the possible role of 'myth and tale' metaphors in the debate, notwithstanding their limitations. I argue that the value of a feminist metaphor for purposes of social change is proportional to its capacity to unsettle, disrupt and question the taken for granted.

\section{METHODS}

What follows is a brief account of how the idea for this research came about, and the methods I have used. I started to discern a 'myth and tale' semantic pattern by serendipity, while researching metaphors on women academics (Moratti, 2018) and by reading scholarly material for a set of empirical studies on gender and tenure (Moratti, 2020a, 2020b). As my intuition gradually took shape, I further investigated the matter through internetmediated qualitative content analysis (Hewson et al., 2016). I opted for qualitative text mining using Google Scholar, currently the most comprehensive academic search engine (Gusenbauer, 2019). Based on an understanding of 'social reality as conceptually mediated', I aimed to shed light on the 'relations between discourse and other social elements (power relations, ideologies, institutions, social identities)' through critical discourse analysis (Fairclough 2012: 9). I searched Google Scholar for 'metaphors women academia'. I ordered results by relevance and without setting a beginning or end date. I browsed the first twenty pages, comprising about 200 entries. Among my results, I retained and read comprehensive reviews of metaphors on women academics (such as Amery et al., 2015) as well as anthologies discussing the topic (such as Black and Garvis, 2018). In addition, I retained and read the papers that displayed striking, powerful metaphors already in their titles or abstracts (including Gallant and Cross, 1993; Harris et al., 2013). Taking these as a starting point in my investigation, I begun to collect my metaphors into a list and saw my intuition confirmed: there was indeed a major stream of metaphors based on fairy tales. At that point I also took notice of the many figurative expressions referencing sagas, legends, 
folklore, classical myths and religious imagery. In a nutshell, I opted for theoretical sampling: 'a process of data collection for generating theory whereby the analyst jointly collects, codes, and analyses ... data and decides which data to collect next and where to find them, in order to develop ... theory as it emerges' (Glaser and Strauss, 1967: 45 , my italics).

The five interpretive categories I use in my analysis: 'status', 'liminality', 'ambivalence', 'reductionism' and 'normativity', unfolded gradually and inductively as my data collection progressed in 'an evolving process guided by the emerging theory' whereby 'analysis occurs simultaneously when identifying the sample and collecting the data' (Merriam and Tisdell, 2016: 99, my italics). It first struck me that several of my metaphors instantiated the gender as status theory (presented below) by encapsulating it into a literary image. Thereafter, I became aware of their semantic duality reflected in what seem to me two clearly distinct characteristics: 'liminality' as the state of being in-between reality and possible worlds, and 'ambivalence' as the quality of simultaneously capturing two extremes, the prodigious and the monstruous. Finally, I reflected on the relationship between reality and 'tale and myth' metaphors, and the 'reductionism' and 'normativity' that can derive from using long-established plots as descriptors for real-life situations. In naming my interpretive categories, I did not seek to draw from the literature but rather chose the names that seemed most appropriate, based on my theoretical intuitions. I aimed for novelty and originality and avoided 'borrowed classification schemes' that could 'create a bias in the data analysis' (Merriam and Tisdell, 2016: 212) and 'hinder the generation of new categories' (Glaser and Strauss, 1967: 37).

I enriched my list of metaphors by perusing articles referenced in the papers I had read, playing with the 'cited by' function in Google Scholar, and directly querying Scholar for tales or myths evoked by analogy (for example, after finding references to Cinderella, I searched 'Snow White women academia'). Once my catalogue of metaphors was compiled based on the procedure described above, further multiple queries of Google Scholar for related strings (such as 'metaphors women academia fairy tales' or 'metaphors women higher education myths') added nothing to my analysis and only a few entries to the catalogue, reported at the bottom of this paper (Table 1). I interpreted this as data saturation. I make no claims to completeness. This paper is not a comprehensive review or an analysis of the frequency of metaphors use in the literature (understood as a linguistic corpus). It is qualitative research and as such it does not ascribe meaning through counting. The thematic focus of this study rests on metaphors of women in higher education, with occasional mentions of figurative expressions used for women in other types of organisations where pertinent. The relevant metaphors are presented discursively, as examples to illustrate each interpretive category.

\section{ANALYSIS}

In my discussion of each interpretive category (presented below), I drew inspiration from a highly multidisciplinary body of literature in Gender Studies, Sociology, Organisation Studies, Literary Studies and Psychology. No attempts are made in this paper to police the boundaries between fields of study: on the contrary, I deliberately create bridges, aiming for originality.

\section{Status}

Men have dominated academia ever since universities were established as independent institutions. In many countries and disciplinary areas, the upper echelons of academia are still predominantly men: the higher up in the hierarchy, the more male dominated it becomes. This situation reflects that of other high-status professions. One of the most intriguing explanations for this state of affairs is based on the theory of gender as status. People gendercategorise one another automatically and unconsciously, and associate gender with desirable characteristics including competence, very relevant in academia where evidence of expertise can be ambiguous and open to interpretation. This categorisation is based on conscious and unconscious assumptions that result from socialisation and reflect historical segregation. These socially diffuse beliefs create, legitimise and reinforce relations of hierarchy and inequality (Mackay et al., 2010; Ridgeway, 2011; Calas et al., 2014). Organisations (including higher education institutions) have a gender regime operating through a daily interplay of deeply held beliefs, patterns and routines that influence decision making in invisible ways, because they are so deeply entrenched and taken for granted that they have come to be regarded as the norm, as the natural state of affairs (Kanter, 1977; Cockburn, 1991; Connell, 2002; Acker, 2006; Van de Brink and Benschop, 2012; Grada et al., 2015; Nielsen, 2016; O'Connor, 2020). 'Tale and myth' metaphors often capture well the status inequality that historically exists between genders, particularly in the professional sphere. In the present section, I will offer some examples of such metaphors.

Some scholars have evoked one of the most classical fairy tale characters: Cinderella, to allude to unfair job tasks allocation in academia linked to the lower status of women. Cinderellas keep their Departments running by taking care of routine work, while being excluded from the most prestigious and rewarding opportunities (Dowling, 1981; Yoder, 1991; Tripp-Knowles, 1995). Some contributions introduce other characters from Perrault's tale as well. Occasionally, Cinderella is fortunate enough to encounter her 'fairy godmother', an experienced female 
mentor who helps her to navigate 'the kingdom' of academia (Harris et al., 2013). Cinderella echoes other popular metaphors on female academics, such as 'housekeeper' and 'housewife' (Delamont, 1989; Suspitsina, 2000; Bagilhole, 2002; Fitzgerald, 2014; Amery et al., 2015). Interestingly, I found that the Cinderella metaphor is used also in academic medicine for under-researched, under-diagnosed and under-treated diseases and low-status branches of medical science: unsurprising, these encompass female sexual dysfunctions, and family and community medicine where women are well-represented. The use of this metaphor is becoming so frequent that some medical scholars ironically refer to the phenomenon as 'cinderology' (Hazelton and Hickey, 2004; Cameron, 2005). Next to the fairy godmother, another central element in Cinderella's story are her magical glass slippers that would only fit her foot and no one else's. In management and diversity studies and in contributions discussing women in the legal profession, a 'glass slippers' metaphor has been introduced to refer to the intersection between occupational and gender identity. Particular jobs and tasks - typically of low status - are socially perceived as 'natural' for women, which reinforces occupational segregation by gender (Skordaki, 1996; Ashcraft, 2013). While not directly used as a metaphor, Cinderella's glass slippers have been hinted at in the literature on gender inequality in academia (Harris et al., 2013). Glass, in various declinations, keeps recurring in the metaphors that seek to describe women's situation in academia by alluding to unequal status. The association between women and glass is time-honoured; glass is invisible and fragile: 'women and glass are always in danger', so goes a well-known old English proverb.

Poor Cinderella will ultimately become the Prince's wife. Royalty, the epitome of status inequality, features prominently in fairy tales and in metaphors on academics, for once including also men. The 'princess' advances professionally thanks to a male protector (Williams, 2005). The 'crown prince' is chosen by influential men for an upcoming professorship or a leadership role, through a covert institutional pre-selection process; his induction is an open secret (Still, 1989; Pullan and Abendstern, 2018).

In essence, I believe 'myth and tale' metaphors offer powerful depictions of the low-visibility gender regime that governs higher education institutions, ultimately founded on a conceptual understanding of gender as status. I will now proceed to discuss other equally striking features of such metaphors.

\section{Liminality}

Unlike metaphors that draw from the natural world or from terminology of engineering and architecture, 'myth and tale' metaphors typically do not imply that women are imprisoned in rigid, unchangeable structures. Myths and tales often open up a liminal, transformational space where 'characters... imagine and construct alternative possibilities from existing precedents' (Nowlin, 2006: 49). Cinderella went from rags to riches, through perils and uncertainty. In the realm of liminality, the 'middle space' between reality and possible-worlds, 'the possibility exists of standing aside... from one's own social position... and of formulating a potentially unlimited series of alternative social arrangements' (Turner, 1974: 14). Lord and Robb (2010) spoke of 'The Canterbury Tales' to designate women academics' first-hand accounts of a traditionally male-dominated field at the University of Canterbury, UK. The Canterbury Tales is a collection of fictional stories, written by Geoffrey Chaucer in the 14th century. Most are fables, centring around discovery, pilgrimage, encounters with fabulous creatures and other liminal, transformational experiences. Academia itself has been described as a 'candied cottage' that lures 'Hansel and Gretel' (Barnard, 2019); an 'ivory tower' where the privileged prosper (Benschop and Brouns 2003; Eveline, 2004; Fitzgerald, 2012; Harris et al., 2013); a 'pyramid' (Morley, 1994); a 'maze' (European Commission, 2008) or 'labyrinth' (Gonzales et al., 2013) where the rules for career progression are not clear, particularly for women. For women, having a tenured academic position and a family is the 'holy grail' (Harris et al., 2013): a sacred, elusive treasure that brings about eternal abundance and happiness. Some of these images are psychological archetypes with a strong symbolic significance, and portals to the dimension of the sacred. 'Tvory tower' is one of the attributes of Mary since the 1587 Litany of the Blessed Virgin. In Egyptian culture, the pyramid is a symbol of creation and resurrection, connecting Earth with the Otherworld. The 'holy' grail sought after by the knights in the Arthurian saga is a reference to Jesus' cup at the Last Supper. The labyrinth evokes the ancient Greek myth of Theseus who found his way in the maze and killed the monstrous Minotaur: some feminist contributions on gendered violence and race actually go as far as using 'minotaur' as a metaphor (Dinnerstein, 1976; Martin, 2014). In several religions, maze emblems are used in meditation and prayer; in psychology, the maze represents the human learning experience, the tortuous but meaningful journey to one's spiritual centre and back into the world. The biblical myth of the Creation is evoked as some contributions refer to historically all-female higher education institutions as 'Adamless Eden' (Palmieri, 1995) and others liken women academics to 'Eve' who was 'punished for having an appetite for knowledge' (Robbins et al., 2008: 50). God's apple is tempting yet dangerous: eating it can only be a transformative experience. Female students who embrace higher education, and particularly Women's Studies, are 'kissing the frog' (Griffin, 2003). Remarkably, even 'Princess Diana' was mentioned in the context of metaphors on women in academia (Griffin, 2003): an actual person whose life and style got so romanticised that she became an icon, the real-life embodiment of the fairy tale princess and a good example of liminality. Even more recurrent are references to the looking glass, which echoes Virginia Woolf's words in her essay A Room of One's Own (1929): 
'women have served all these centuries as looking glasses possessing the magic and delicious power of reflecting the figure of man at twice its natural size' (Woolf 1998[1929]: 45, my italics). There is a powerful symbology associated with the looking glass, threshold of change, portal of discovery bridging reality and the marvellous (Arlandis and Reyes-Torres, 2018). Drawing inspiration from Deleuze (1969), women academics have been compared to Carroll's Alice Through the Looking-Glass as well as Alice in Wonderland (Patterson, 1971; Chouinard, 1995; McMillan and Price, 2010; Netolicky et al., 2018). By eating magical food, Alice repeatedly adjusts her size to enter doors that are too small for her, or to reach tables that are too high. The metaphor alludes to 'academia... designed through time to routinely accommodate the work needs of the male professional' and demanding strenuous adjustment efforts from women, that are however possible, albeit difficult (Patterson, 1971: 227). The 'Alice through the lookingglass' metaphor is also used to refer to gendered gatekeeping practices in the allocation of prestigious job tasks in higher education institutions, made by manipulating 'perceptions of what constitutes legitimate research' (McMillan and Price, 2010: 145). When used in this sense, the metaphor manages to capture both status inequality and liminality.

The two features of 'myth and tale' metaphors discussed so far, their capacity to represent status inequality while at the same time not portraying women as trapped, make them better depictions of gender inequity in higher education than their engineering, architecture and natural world-based counterparts. However, 'myth and tale' metaphors have limitations too. They contribute to othering women scholars, as explained in the next section.

\section{Ambivalence}

Another central element in metaphors based on fairy tales and fantasy, legends and sagas, folklore, mythology and religious imagery is ambivalence. The 'otherness' of women academics, their non-conformity in traditional maledominated professions led to conceptualising them as monsters or prodigies, with metaphors such as intellectual Frankenstein' (Palmieri, 1995; Netolicky et al., 2018); 'Superwoman' (Suspitsina, 2000); 'Wonder Woman' (Martimianakis, 2008; Bozzon et al., 2017); 'mermaid' (Anderson, 2008). The very term 'monster' is semantically ambiguous in Latin (monstrum) and ancient Greek ( $\tau \dot{\varepsilon} \varrho a \varsigma$ ). It can mean marvel, wonder, prodigy, freak or demon with a negative aesthetic and moral connotation. Along with ambiguity, magic and horror surface often in 'myth and tale' metaphors on women academics, that include 'witch' and 'witches' coven' for panels or groups (Fisher, 2007; Cabral-Cardoso, 2008). Women live in the 'academic twilight zone' (Kroll, 2006), particularly if they are foreigners (Cheng, 2005). Female academics are 'outsiders in the sacred grove' (Aisenberg and Harrington, 1988) and 'strangers', a metaphor 'developed from the Wandering Jew' (Czarniawska and Sevón 2008: 237; also see Simmel, 1950[1909]). The tale of women walking the 'hallowed halls of academia' can turn into 'a horror story' (Procopio et al., 2016). Academia, the 'greedy institution' that demands 'undivided commitment' (Coser, 1974), has been metaphorically described as a 'vampire' for its impact on the lives of women (Kroll, 2006). In her autoethnography, a young academic referred to herself as 'Buffy the Vampire Slayer' (Netolicky et al., 2018). 'Iron maiden' is used for 'competent and forthright' women academics (Kanter, 1977). The reference to iron here symbolises permanence and the suppression of the emotional sphere. The ambivalence built into 'myth and tale' metaphors extends beyond the portrayal of individual female academics. These metaphors also narrate 'female experience under patriarchy, a world in which innocent young women are set against their sisters and mothers in rivalry for the prince's favour' (Fisher and Silber, 2000: 121). The 'queen bee' (Ellemers et al., 2004; Kinney, 2009; Cummins, 2012; Mansingh and Khan, 2020), consumed by 'Venus' envy' (Mavin, 2006: 264), actively keeps more junior female colleagues from advancing professionally in her 'queendom' (Ballif et al., 2008: 119).

I believe the ambivalence of many 'myth and tale' metaphors is a shortcoming of this cluster of figurative expressions. They contribute to othering women: by depicting women academics as an anomaly, these metaphors ultimately normalise women's traditional condition of non-belonging in academia. The same considerations hold for portraying academic rivalry as a specifically feminine deficiency, when the people involved happen to be women. In the subsequent sections, I will discuss two more important limitations that I see in metaphors falling under this cluster.

\section{Reductionism}

'Myth and tale' metaphors are certainly fascinating. Notwithstanding their 'predictable narrative thread', 'traditional depictions of gender' have a 'palpable fairy tale appeal' (Kinney 2009: 151; see also Ballif et al., 2008). Prominent psychoanalyst Bruno Bettelheim suggested that fairy tales and myths 'help readers see themselves in stories of conflict, and thus move them closer to naming their anxieties' (Bettelheim, 1976, cited in Kinney 2009: 151; also see Dundes, 1980). The benefits of identification may extend to feeling less isolated: one is, in essence, re-living a familiar plot that is being experienced by other members of one's same group - assuming that the degrees of complexity of reality and fiction are comparable. I believe this assumption is problematic. It has been convincingly argued that there are a limited number of plots in fiction. Indexes have been compiled for fairy tales and folklore (for example, the Aarne-Thompson-Uther Index: Thompson, 1989; Uther 2004). In his relatively recent but 
already classic theorisation, Booker (2004) compellingly argued that there exist only seven basic plots in fiction: overcoming the monster; rags to riches; the quest; voyage and return; rebirth; and comedy or tragedy (depending on whether the main character gets his or her hopes fulfilled). The reader can easily fit each of our above-discussed metaphors into one of these archetypal plots: the interesting question is whether people's lives and experiences can also be fitted into a limited number of plots, or patterns of plots. The use of 'myth and tale' metaphors could amount to taking a cognitive shortcut by relying on an already familiar storyline, an a-priori explanation of social phenomena. In this way, metaphors could obfuscate the complexity of social phenomena rather than illuminate it. Interestingly, an 'archetypal plots' approach is used in career counselling: the same seven basic plots that underlie 'the greatest works of the human imagination in the arts and humanities' also offer 'a conceptually coherent account of the role of unplanned events in individuals' experiences and careers' (Pryor and Bright, 2008: 76). 'Society's grand narrative of a career' (Savickas, 2005: 49, my italics) guides people's interpretation of their own professional hurdles: by problematising such interpretations, the counsellor opens up new perspectives for the individual client. In essence, 'what individuals often attempt to do is to use closed-systems thinking... to deal with an open-systems reality' (Pryor and Bright, 2008: 78, my italics). I believe that is, in essence, a form of reductionism, and it constitutes a major limitation of 'myth and tale' metaphors.

In conclusion, attempts to fit real-world situations into a limited number of plots (reductionism) can be a way of eluding the complexities of life, by embracing a familiar and predictable narrative in which to evade. The possible world generated by the 'myth and tale' metaphor can become a refuge from engaging with reality. In the subsequent section, I will further develop my argument and contend that reductionism is closely linked with normativity, another limitation of 'myth and tale' metaphors.

\section{Normativity}

Some fictional stories have a great power of mental attraction, particularly religious and ancient myths with their elegance and charm. Their roots run deep in our collective subconscious. Metaphors based on them can become normative, by creating expectations as to the likely outcome of a situation and implicitly suggesting a course of action. This is true even for metaphors based on children' tales such as Cinderella, Alice or Snow White (Trahar, 2019), and it is even more true for myths with their solemnity and magnetism.

I, for one, am guilty as charged: myth-based metaphors are so captivating that I considered using one myself. I studied one decade of professorial hiring through open calls at one Faculty of the biggest University in Norway, attracting over a thousand applicants overall. I found that women (and only women) are advantaged when already working at the institution (internal applicants) and disadvantaged when external applicants. Women apply as external applicants nearly as much as men do, but tend not to be preferred (Moratti, 2020b). This is especially true for women applicants affiliated with a non-Norwegian institution. I considered calling this pattern of findings 'the Ulysses-Penelope effect'. Ulysses was a king, a war hero and a traveller: a 'man skilled in all ways of contending' who 'saw the townlands and learned the minds of many distant men' (Homer, 1961: 273). While he explored and conquered, his wife Penelope, the epitome of loyalty, patience and perseverance, waited at home for decades. Her wanderer husband was not faithful, but Penelope was. I hypothesised that evaluators may be influenced by traditional gender roles. The feminine role is that of the faithful Penelope, who can be retained after her loyalty has been duly tried and tested: women, with respect to men, may have to work harder to build institutional rapport before they are hired permanently. Unsurprisingly, I also found that women held the vast majority of temporary senior lecturer contracts at that Faculty in the decade considered and in the years that preceded it ('senior' means reserved to candidates with a $\mathrm{PhD}$ ). Ulysses, the conqueror, the discoverer, the prestigious international scholar, is a symbol for masculinity. Ulysses' qualities are seen as prerogatives of the masculine: when women try to perform those exact same masculinities, they are received differently.

However, I paused, and eventually dropped the idea of making reference to Ulysses and Penelope in my interpretation. Was I merely photographing the existent, or was I contributing to perpetuating stereotypes? Was I illuminating the phenomenon I was investigating, or rather clouding it by activating imaginaries linked to genderrole clichés? More importantly, I questioned my fascination with myth and ancient tales. I was constructing a reductionist and normative fictional world, to constrain complex social phenomena into a familiar narrative borrowed from one of the greatest storytellers in human history. The magnetism of the Odyssey's plot enchants the reader, leaving little room for divergent interpretations of trends in the data.

Some of the most fascinating metaphors on gender equality work in academia are based on myths: such work has been described as 'arming Athena', after the goddess of knowledge, arts and military strategies (Stalker, 1994; Collins et al., 1998). Athena was the favourite daughter of Zeus, born adult and fully armed from the head of her father. No uterus or vagina were involved in her birth, she never had a childhood, she was portrayed as a virgin, and brains and pugnacity were her key features: while interesting, this metaphor is certainly suggestive as to the imageries of the 'ideal academic' (Thornton, 2013), and their poor compatibility with the female body, the emotional sphere and traditional feminine social roles, including care and motherhood. Gender equality work has 
also been compared to a mythical 'quest': that of slaying the seven-headed dragon' (Van den Brink and Benschop, 2012: 71). The phrase implicitly alludes to the Beast with seven heads in the Book of Revelation, and evokes the Greek myth of the seven-headed Hydra. The Beast was defeated by Saint Michael and his angels, and the mythical god-hero Hercules eventually triumphed over the Hydra, notwithstanding the extreme resilience of the monster: every time one of its heads got severed, two new heads grew, so the legend goes. Does such a metaphor, however elegant and captivating, suggest that only saints or heroes can hope to successfully resist structural inequality? Myth-based metaphors have been used also for gender equality work in organisations in general, not limited to academia. Women who do such work are 'Sisyphus' sisters' (Benschop and Verloo, 2006). Sisyphus was the mythological king of Corinth, punished by Zeus with the torture of forever pushing a rock up a hill, only for it to roll back down again. Gender regimes in organisations are highly resilient; but unlike Sisyphus, his sisters make tangible progress and start from a slightly improved position each time. However, the mythological Sisyphus did not have sisters. This particular metaphor has the merit of playing creatively with an existing myth, effectively reinventing it and re-defining its meaning: this considerably weakens (but still, does not manage to eliminate) the reductionist and normative force of the myth-based metaphor.

Normativity is the direct consequence of reductionism, interpreted (as I do) as the attempt to understand a social phenomenon through an existing fictional plot. By normativity, I mean that 'myth and tale' metaphors can prescribe behaviour: one may be inclined to draw inspiration from the actions of the hero in the story, and believe that therein lies the solution to the social problem that the metaphor alludes to - but that is not necessarily the case.

\section{CONCLUSIONS}

I have pointed out the main limitations of the use of 'myth and tale' metaphors to refer to women academics, or to academia and women's position in it. I have acknowledged the interesting and convincing features of such metaphors, too: many of them convey well the status disparity between genders that has historically characterised the academic profession, and hint to a dimension of possibility (liminality) that goes beyond the current state of affairs, a possible-world where women scholars, their aspirations and talents are nurtured and fully valued. However, 'myth and tale' metaphors are typically othering women who trespass into the traditional male territory of academia, by depicting them as monsters or wonders far removed from the human sphere: this seems to express a degree of suspicion (ambivalence). Even more importantly, there is evidence that myths and tales, ancient and modern, can be subsumed under a limited number of storylines, the so-called archetypal plots: but real-life social phenomena do not necessarily adhere to such plots (reductionism). Images borrowed from myths and tales reconduct us to familiar narratives, possibly to evade from too incomprehensible and intricate a reality. They trigger expectations as to the outcome of a situation and implicitly prescribe behaviour: do as the hero in the story and you will get out of your predicament; or, if the hero acted foolishly, do not make that same mistake (normativity). It is easy to see where the intersection between reductionism and normativity can lead: implicit behavioural prescriptions that, when followed in practice, do not lead to the intended result.

What remains to be seen is whether there can still be merit in the use of 'myth and tale' metaphors, despite their limitations. I would like to put forward two suggestions. Firstly, it is perhaps wise to be sceptical of attempts to create yet another grand narrative that claims to apply to all women academics. Rather than postulating general models aspiring to universal validity, it is preferable that women actively recount their own stories and the meaning they attribute to them (for instance, through auto-ethnography) and coin metaphors they feel apply to their own experiences, such as 'Buffy the Vampire Slayer' (Netolicky et al., 2018). Secondly, playing creatively with an existing tale or myth is more interesting than merely borrowing one of its elements. For example, one could re-tell the tale by adding characters or plot twists that are not part of the fictional story alluded to. In addition to making the metaphor more original, this unorthodox and creative editing weakens the normative and reductionist effect of the metaphor (see as an example Benschop and Verloo, 2006). More generally, feminist thinkers see value in unsettling conventional categories and questioning the taken for granted, possibly through irony and paradox (Butler, 1990; Ahmed, 2003). The mission of the feminist metaphor is to trouble received wisdom, and the value of a metaphor for purposes of social change is proportional to its potential to dismpt and unsettle conventional thinking. 
Table 1. Metaphors derived from fairy tales, fantasy, sagas, mythology and religious imagery, and referring to women academics as individuals; their institutions, success models and experiences; and to the study of gender as a field of knowledge as well as gender equality work in academia

\begin{tabular}{|c|c|c|c|}
\hline & On individuals & $\begin{array}{l}\text { On institutions, success } \\
\text { models and experiences }\end{array}$ & $\begin{array}{l}\text { On studying gender and } \\
\text { on gender equality work }\end{array}$ \\
\hline $\begin{array}{l}\text { Fairy tales } \\
\text { and fantasy }\end{array}$ & $\begin{array}{l}\text { Cinderella } \\
\text { (Dowling, 1981; Yoder, 1991; Tripp-Knowles, } \\
\text { 1995) } \\
\text { The Fairy Godmother } \\
\text { (Harris et al., 2013) } \\
\text { Witch } \\
\text { (Fisher, 2007) } \\
\text { Alice } \\
\text { (Patterson, 1971; Chouinard, 1995; McMillan } \\
\text { and Price, 2010; Netolicky et al., 2018) } \\
\text { Snow White } \\
\text { (Trahar, 2019) } \\
\text { Queen Bee } \\
\text { (Ellemers et al., 2004; Mavin, 2006; Kinney, } \\
\text { 2009; Cummins, 2012; Mansingh and Khan } \\
\text { 2020) } \\
\text { Princess } \\
\text { (Griffin, 2003; Williams, 2005) } \\
\text { Crown Prince } \\
\text { (Still, 1986; Pullan and Abendstern, 2018) } \\
\text { Pollyanna } \\
\text { (Ferree and Zippel, 2015) } \\
\text { Intellectual Frankenstein } \\
\text { (Palmieri, 1995; Netolicky et al., 2018) } \\
\text { Superwoman } \\
\text { (Suspitsina, 2010) } \\
\text { Wonder Woman } \\
\text { (Martimianakis, 2008; Bozzon et al., 2017) } \\
\text { Buffy the V ampire Slayer } \\
\text { (Netolicky et al., 2018) }\end{array}$ & $\begin{array}{l}\text { Glass slippers } \\
\text { (Skordaki, 1996; Ashcraft, 2013) } \\
\text { The Kingdom } \\
\text { (Harris et al., 2013) } \\
\text { The Queendom (of Queen Bee) } \\
\text { (Ballif et al., 2008) } \\
\text { Candied cottage } \\
\text { (Barnard, 2019) } \\
\text { Vampire (greedy institution) } \\
\text { (Kroll, 2006) } \\
\text { The academic twilight zone } \\
\text { (Cheng, 2005; Kroll, 2006) }\end{array}$ & $\begin{array}{l}\text { Kissing the frog } \\
\text { (Griffin, 2003) } \\
\text { Witches' coven } \\
\text { (Fisher, 2007) } \\
\text { Seeking Yoda } \\
\text { (Hutchinson, 2002) }\end{array}$ \\
\hline $\begin{array}{l}\text { Sagas, } \\
\text { mythology, } \\
\text { religious } \\
\text { imagery }\end{array}$ & $\begin{array}{l}\text { Iron maiden } \\
\text { (Kanter, 1977) } \\
\text { Mermaid } \\
\text { (Anderson, 2008) } \\
\text { Cassandra } \\
\text { (Ferree and Zippel, 2015) } \\
\text { Venus envy } \\
\text { (Marvin, 2006) } \\
\text { Eve } \\
\text { (Robbins et al., 2008) } \\
\text { Strangers (developed from the Wandering Jew) } \\
\text { (Czarniawska and Sevón, 2008; Amery et al., } \\
\text { 2015) } \\
\text { Martyrs } \\
\text { (Czarniawska and Sevón, 2008) } \\
\text { Wayward puritans } \\
\text { (Gallant and Cross, 1993) }\end{array}$ & $\begin{array}{l}\text { The hallowed halls of academia } \\
\text { (Procopio et al., 2016) } \\
\text { Iron cage (refers to "Victorian } \\
\text { literary beroines") } \\
\text { (Morley, 1994) } \\
\text { Holy Grail } \\
\text { (Harris et al., 2013) } \\
\text { Canterbury Tales } \\
\text { (Lord and Robb, 2010) } \\
\text { Pyramid } \\
\text { (Morley, 1994) } \\
\text { Maze, labyrinth (evokes myth of } \\
\text { Theseus) } \\
\text { (European Commission, 2008; } \\
\text { Gonzales et al., 2013) } \\
\text { Eden } \\
\text { (Palmieri, 1995) } \\
\text { Ivory tower (comes from the Bible) } \\
\text { (Benschop and Brouns, 2003; } \\
\text { Harris et al., 2013) } \\
\text { Sacred grove (Aisenberg and } \\
\text { Harrington, 1988) }\end{array}$ & $\begin{array}{l}\text { Slaying the seven-headed dragon } \\
\text { (evokes myth of Hydra and } \\
\text { Bible) } \\
\text { (Van den Brink and } \\
\text { Benschop, 2012) } \\
\text { Arming Athena } \\
\text { (Stalker, 1994; Collins et al., } \\
\text { 1998) } \\
\text { Sisyphus' sisters } \\
\text { (Benschop and Verloo, } \\
\text { 2006) }\end{array}$ \\
\hline
\end{tabular}




\section{REFERENCES}

Acker, J. (1990). Hierarchies, Jobs, Bodies: A Theory of Gendered Organizations. Gender \& Society, 4(2), 139-158. https://doi.org/10.1177/089124390004002002

Ahmed, S. (2003). Living a Feminist Life. Durham: Duke University Press.

Aisenberg, N. and Harrington, M. (1988). Women of Academe: Outsiders in the sacred grove. Amherst, MA: University of Massachusetts Press.

Amery, F., Bates, S., Jenkins, L. and Savigny, H. (2015). Metaphors on Women in Academia: A Review of the Literature, 2004-2013, in V. Demos and M. Texler-Segal (eds), At the Center: Feminism, social science and knowledge (pp. 245-267). Bingley, UK: Emerald Group Publishing. https://doi.org/10.1108/S1529-212620150000020022

Anderson, J. K. (2008). An Academic Fairy Tale: A Metaphor of the Work-Role Transition from Clinician to Academician. Nurse Educator, 33(2), 79-82. https://doi.org/10.1097/01.NNE.0000299511.70646.ab

Arlandis, S. and Reyes-Torres, A. (2018). Thresholds of Change in Children's Literature: The Symbol of the Mirror. Journal of New Approaches in Educational Research, 7(2), 125-130. https://doi.org/10.7821/naer.2018.7.275

Ashcraft, K. (2013). The Glass Slipper: 'Incorporating' Occupational Identity in Management Studies. Academy of Management Review, 38(1), 6-31. https://doi.org/10.5465/amr.2010.0219

Bagilhole, B. (2002). Women in Non-Traditional Occupations. London, UK: Palgrave Macmillan. https:// doi.org/10.1057/9780230501102

Bagilhole, B. and Goode, J. (2001). The Contradiction of the Myth of Individual Merit, and the Reality of a Patriarchal Support System in Academic Careers: A Feminist Investigation. European Journal of Women's Studies, 8(2), 161-180. https://doi.org/10.1177/135050680100800203

Ballif, M., Davis, D. and Mountford, R. (2008). Women's Ways of Making It in Rhetoric and Composition. New York, NY: Routledge.

Barnard, A. (2019). Developing Researcherhood: Identity Tensions and Identity Work of Women Academics Reflecting on Their Researcher Identity. Forum Qualitative Sozialforschung / Forum: Qualitative Social Research, 20(3). Available at: https://www.qualitative-research.net/index.php/fqs/article/view/3238. (Accessed 11 April 2021).

Bendl, R. and Schmidt, A. (2010). From 'Glass Ceilings' to 'Firewalls' - Different Metaphors for Describing Discrimination. Gender, Work \& Organization, 17(5), 612-634. https://doi.org/10.1111/j.14680432.2010.00520.x

Benschop, Y. and Brouns, M. (2003). Crumbling Ivory Towers: Academic Organizing and its Gender Effects. Gender, Work \& Organization, 10(2), 194-212. https:// doi.org/10.1111/1468-0432.t01-1-00011

Benschop, Y. and Brouns, M. (2009). The Trouble with the Glass Ceiling: Critical Reflections on a Famous Concept, in J. W. Cox, T. G. LeTrent-Jones, M. Voronov and D. Weir (eds), Critical Management Studies at Work: Negotiating tensions between theory and practice (pp. 259-270). Cheltenham, UK: Edward Elgar Publishing.

Benschop, Y. and Dooreward, H. (1998). Covered by Equality: The Gender Subtext of Organizations. Organization Studies, 19(5), 787-805. https://doi.org/10.1177/017084069801900504

Benschop, Y. and Verloo, M. (2006). Sisyphus' Sisters: Can Gender Mainstreaming Escape the Genderedness of Organizations? Journal of Gender Studies, 15(1), 19-33. https:/ / doi.org/10.1080/09589230500486884

Bettelheim, B. (1976). The Uses of Enchantment: The meaning and importance of fairy tales. New York, NY: Knopf.

Black, A. L. and Garvis, S. (eds). (2018). Lived Experiences of Women in Academia: Metaphors, manifestos and memoir. New York, NY: Routledge. https://doi.org/10.4324/9781315147444

Booker, C. (2004). The Seven Basic Plots: Why we tell stories. London: Continuum.

Bozzon, R., Murgia, A. and Villa, P. (2017). Precariousness and Gender Asymmetries Among Early Career Researchers: A Focus on STEM Fields in the Italian Academia. Polis, 31(1), 127-158. https://doi.org/10.1424/86082

Butler, J. (1990). Gender Trouble: Feminism and the subversion of identity. London: Routledge.

Cabral-Cardoso, C. (2008). The Unscrupulous Careerist, the Morally Fake, the Queen Bee, and the Wicked Witch: The Dark Side of Female Politics in Academia. Unpublished paper, 'The Dark Side of Organization' Conference, Sheffield, 25th-27th June. Available at https://repositorio-aberto.up.pt/handle/10216/94529. (Accessed on 21 April 2021).

Cameron, S. M. (2005). Cinderella Revisited. British Medical Journal, 331(7531), 1543-1544. https://doi.org/10.1503/cmaj.1041466

Cheng, S. J. A. (2005). Foreign-Born Women Academics in the US. Feminist Collections: A Quarterly of Women's Studies Resources, 27(1), 11-15. https:/ / doi.org/10.1007/s10734-005-1976-4

Chouinard, V. (1995). Like Alice Through the Looking Glass: Accommodation in Academia. Resources for Feminist Research, 24(3/4), 3-11. 
Collins, L. H., Chrisler, J. C. and Quina, K. (1998). Career Strategies for Women in Academia: Arming Athena. Newcastle upon Tyne, UK: Sage.

Coser, L. A. (1974). Greedy Institutions: Patterns of undivided commitment. New York: The Free Press.

Cummins, H. A. (2012). Queen Bees and Mommy Tracking: How's an Academic Woman Supposed to get Ahead? Advancing Women in Leadership, 32(1), 79-91. https:/ / doi.org/10.18738/awl.v32i0.90

Czarniawska, B. and Sevón, G. (2008). The Thin End of the Wedge: Foreign Women Professors as Double Strangers in Academia. Gender, Work \& Organization, 15(3), 235-287. https://doi.org/10.1111/j.14680432.2008.00392.x

Delamont, S. (1989). Knowledgeable Women. London: Routledge.

Deleuze, G. (1969). The Logic of Sense. (trans. M. Lester). New York, NY: Columbia University Press.

Dinnerstein, D. (1976). The Mermaid and the Minotaur: Sexual arrangements and buman malaise. New York, NY: Other Press.

Disch, L. and Hawkesworth, M. (eds). (2016). The Oxford Handbook of Feminist Theory. Oxford, UK: Oxford University Press. https://doi.org/10.1093/oxfordhb/9780199328581.001.0001

Dowling, C. (1981). The Cinderella Complex: Women's hidden fear of independence. New York: Summit.

Dundes, A. (1980). Projection in Folklore: A Plea for Psychoanalytic Semiotics, in A. Dundes, Interpreting Folklore (pp. 33-61). Bloomington: Indiana University Press.

Ellemers, N., Van den Heuvel, H., De Gilder, D., Maass, A. and Bonvini, A. (2004). The Underrepresentation of Women in Science: Differential Commitment or the Queen Bee Syndrome? British Journal of Social Psychology, 43(3), 315-338. https:// doi.org/10.1348/0144666042037999

European Commission, Directorate-General for Research. (2008). Mapping the Maze: Getting more women to the top in research. Luxembourg: Publications Office of the European Union.

Eveline, J. (2004). Ivory Basement Leadership: Power and invisibility in the changing university. Crawley: University of Western Australia Press.

Fairclough, N. (2012). Critical Discourse Analysis, in J. P. Gee and M. Handford (eds), The Routledge Handbook of Discourse Analysis (pp. 9-20). Oxford: Routledge. https://doi.org/10.4324/9780203809068

Ferree, M. M. and Zippel, K. (2015). Gender Equality in the Age of Academic Capitalism: Cassandra and Pollyanna Interpret University Restructuring. Social Politics: International Studies in Gender, State \& Society, 22(4), 561-584. https://doi.org/10.1093/sp/jxv039

Fisher, G. (2007). You Need Tits to get on Round Here: Gender and Sexuality in the Entrepreneurial University of the 21st Century. Ethnography, 8(4), 503-517. https:/ / doi.org/10.1177/1466138107083565

Fisher, J. and Silber, E. S. (2000). Good and Bad Beyond Belief: Teaching Gender Lessons Through Fairy Tales and Feminist Theory. Women's Studies Quarterly, 28(3/4), 121-136.

Fitzgerald, T. (2012). Ivory Basements and Ivory Towers, in T. Fitzgerald, J. White and H. M. Gunter (eds), Hard Labour? Academic work and the changing landscape of higher education (pp. 113-135). Bingley, UK: Emerald Group Publishing. https://doi.org/10.1108/S1479-3628(2012)0000007007

Fitzgerald, T. (2014). Women Leaders in Higher Education: Shattering the myths. London: Routledge. https://doi.org/10.4324/9780203491515

Fotaki, M. (2013). No Woman is like a Man (in Academia): The Masculine Symbolic Order and the Unwanted Female Body. Organization Studies, 34(9), 1251-1275. https://doi.org/10.1177/0170840613483658

Gallant, M. J. and Cross, J. E. (1993). Wayward Puritans in the Ivory Tower: Collective Aspects of Gender Discrimination in Academia. Sociological Quarterly, 34(2), 237-256. https://doi.org/10.1111/j.15338525.1993.tb00389.x

Gherardi, S. (1995) Gender, Symbolism and Organizational Cultures. London: Sage.

Glaser, B. G. and Strauss, A. (1967) The Discovery of Grounded Theory: Strategies for qualitative research. Chicago: Aldine. https://doi.org/10.1097/00006199-196807000-00014

Goatly, A. (2007). Washing the Brain: Metaphor and bidden ideology. Amsterdam/Philadelphia: John Benjamins Publishing Company. https://doi.org/10.1075/dapsac.23

Gonzales, L. D., Murakami, M. and Núñez A-M. (2013). Latina Faculty in the Labyrinth: Constructing and Contesting Legitimacy in Hispanic Serving Institutions. Educational Foundations, 27(1-2), 65-89.

Griffin, G. (2003). Kissing the Frog: The Impact of Higher Education Reforms in the UK on Women's Studies and on Women Students, in C. Michel, S. Bieri, N. Imboden and C. Seith (eds), Hochschulreform Macht Geschlecht. Aktuelle Reformprozesse an Hochschulen aus feministischer Sicht (pp. 39-50). Bern, Switzerland: Bundesamt für Bildung und Wissenschaft.

Gusenbauer, M. (2019). Google Scholar to Overshadow Them All? Comparing the Sizes of 12 Academic Search Engines and Bibliographic Databases. Scientometrics, 118(1), 177-214. https://doi.org/10.1007/s11192-0182958-5 
Harris, C., Ravenswood, K. and Myers, B. (2013). Glass Slippers, Holy Grails and Ivory Towers: Gender and Advancement in Academia. Labour \& Industry: A Journal of the Social and Economic Relations of Work, 23(3), 231 244. https://doi.org/10.1080/10301763.2013.839084

Hazelton, L. and Hickey, C. (2004). Cinderology: The Cinderella of Academic Medicine. Canadian Medical Association Journal (CMAJ), 171(12), 1495-1496. https://doi.org/10.1503/cmaj.1041466

Hewson, C., Vogel, C. and Laurent, D. (2016). Internet Research Methods (2 ${ }^{\text {nd }}$ edition). London: SAGE. https://doi.org/10.4135/9781473920804

Hines, C. (1999). Rebaking the Pie. The Woman as Dessert Metaphor, in M. Bucholtz, A. C. Liang and L. A. Sutton (eds), Reinventing Identities. The gendered self in discourse (pp. 145-162). Oxford: Oxford University Press.

Homer. (1961). Odyssey (trans. R. Fitzgerald). New York: Doubleday.

Husu, L. (2000). Gender Discrimination in the Promised Land of Gender Equality. Higher Education in Europe, 25(2), 221-228. https://doi.org/10.1080/713669257

Husu, L. (2001). On Metaphors on the Position of Women in Academia and Science. NORA: Nordic Journal of Women's Studies, 9(3), 172-181. https://doi.org/10.1080/713801035

Hutchinson, T. (2002). Seeking Yoda: Mentoring Women Legal Academics. Queensland University of Technology Law and Justice Journal, 2(2), 175-197. https:/ / doi.org/10.5204/qutlr.v2i2.99

Kanter, R. M. (1977). Men and Women of the Corporation. New York, NY: Basic Books.

Kemp, L. J. (2016). 'Trapped' by Metaphors for Organizations: Thinking and Seeing Women's Equality and Inequality. Human Relations, 69(4), 975-1000. https://doi.org/10.1177/0018726715621612

Kinney, K. (2009). Of Queen Bees and Queendoms: Fairy Tales, Resilience, and Women's Ways of Making it in Rhetoric and Composition. Writing Program Administration, 32(3), 150-154.

Kroll, J. (2006). Draining Creativity: The Teacher-Writer in the Vampire Academy. Available at: http:/ /www.textjournal.com.au/oct06/kroll.htm. (Accessed on 21 April 2021).

Kumra, S., Simpson, R. and Burke, R. J. (eds). (2014). The Oxford Handbook of Gender in Organizations. Oxford, UK: Oxford University Press. https://doi.org/10.1093/oxfordhb/9780199658213.001.0001

Kvande, E. (2007). Doing Gender in Flexible Organizations. Bergen: Fagbokforlaget.

Lakoff, G. (1987). Women, Fire, and Dangerous Things: What categories reveal about the mind. Chicago, IL: University of Chicago Press. https://doi.org/10.7208/chicago/9780226471013.001.0001

Leonard, P. (2002). Organizing Gender? Looking at Metaphors as Frames of Meaning in Gender/Organizational Texts. Gender, Work \& Organization, 9(1), 60-80. https://doi.org/10.1111/1468-0432.00149

Lord, B. and Robb A. (2010). Women Students and Staff in Accountancy: The Canterbury Tales. Accounting History, 15(4), 529-558. https://doi.org/10.1177/1032373210372956

Mansingh, A. R. and Khan, M. S. (2020). Move Over, Ms. Professor! A Review of the Challenges Women Experience in Academia. Journal of Higher Education Service Science and Management, 3(1), 1-14.

Martimianakis, M. A. T. (2008). Reconciling Competing Discourses: The University of Toronto's Equity, in A. Wagner, S. Acker and K. Mayzumi (eds), Whose University is It, Anyway? Power and privilege on gendered terrain (pp. 44-60). Toronto: Sumach Press.

Martin, J. M. (2014). Slaying the Minotaur. The Judges' Journal, 53, 14.

Mavin, S. (2006). Venus Envy: Problematizing Solidarity Behaviour and Queen Bees. Women in Management Review, 21(4), 264-276. https:// doi.org/10.1108/09649420610666579

McMillan, S. and Price, M. A. (2010). Through the Looking Glass: Our Autoethnographic Journey through Research Mind-Fields. Qualitative Inquiry, 16(2), 140-147. https://doi.org/10.1177/1077800409350696

Merriam, S. B. and Tisdell, E. J. (2016). Qualitative Research: A guide to design and implementation (4th edition). San Francisco, CA: Wiley.

Moratti, S. (2018). What's in a Word? On the Use of Metaphors to Describe the Careers of Women Academics. Gender and Education, 32(7), 862-872. https://doi.org/10.1080/09540253.2018.1533927

Moratti, S. (2020a). Do Low-Openness, Low-Transparency Procedures in Academic Hiring Disadvantage Women? Social Sciences, 9(6), 89-102. https://doi.org/10.3390/socsci9060089

Moratti, S. (2020b). A Woman's Place is in the 'Home'? Gender-Specific Hiring Patterns in Academia in GenderEqual Norway. Joumal of Sociology (e-published ahead of print). https://doi.org/10.1177/1440783320960530

Morgan, G. (1986). Images of Organization. London, UK: SAGE.

Morley, L. (1994). Glass Ceiling or Iron Cage: Women in UK Academia. Gender, Work \& Organization, 1(4), $194-$ 204. https://doi.org/10.1111/j.1468-0432.1994.tb00018.x

Netolicky, D., Barnes, N. and Heffernan, A. (2018). Metaphors for Women's Experiences of Early Career Academia: Buffy, Alice, and Frankenstein's Creature, in A. Black and S. Garvis (eds), Lived Experiences of Women in Academia: Metaphors, manifestos and memoir (pp. 171-180). London: Routledge. https://doi.org/10.4324/9781315147444-17 
Nowlin, S. (2006). Between Precedent and Possibility: Liminality, Historicity, and Narrative in Chaucer's 'The Franklin's Tale'. Studies in Pbilology, 103(1): 47-67. https://doi.org/10.1353/sip.2006.0005

Palmieri, P. A. (1995). In Adamless Eden: The community of women faculty at Wellesley. New Haven, CT: Yale University Press.

Patterson, M. (1971). Alice in Wonderland: A Study of Women Faculty in Graduate Departments of Sociology. The American Sociologist, 6(3), 226-234.

Peterson, H. (2014). An Academic 'Glass Cliff? Exploring the Increase of Women in Swedish Higher Education Management. Athens Journal of Education, 1(1), 33-44. https:// doi.org/10.30958/aje.1-1-3

Procopio, C. H., Tate, H., Sheeler, K. H., Hoffmann-Longtin, K., Feldner, S. and Anderson, K. V. (2016). Horror Stories from the Hallowed Halls of Academia: How Six Women Lived to Tell the Tale, in E. Wright II and T. C. Calhoun (eds), What to Expect and How to Respond: Distress and success in academia (pp. 153-170). Lanham/Boulder/New York/London: Rowman \& Littlefield.

Pryor, R. G. and Bright, J. E. (2008). Archetypal Narratives in Career Counselling: A Chaos Theory Application. International Journal for Educational and Vocational Guidance, 8(2), 71-82. https://doi.org/10.1007/s10775-0089138-8

Pullan, B. and Abendstern, M. (2018). A History of the University of Manchester 1973-90. Manchester, UK: Manchester University Press. https://doi.org/10.7765/9781526137197

Robbins, W., Sutherland, R. and Luo, S. P. (2008). Searching for our Alma Maters: Women Professors in Canadian Fiction Written by Women. Journal of Canadian Studies, 42(2), 43-72. https:/ / doi.org/10.3138/jcs.42.2.43

Savickas, M. L. (2005). The Theory and Practice of Career Construction, in R. W. Lent and S. D. Brown (eds), Career Development and Counseling: Putting theory and research to work (pp. 42-70). Hoboken, NJ: John Wiley \& Sons.

Simmel, G. (1950). The Stranger, in K. Wolff (ed), The Sociology of Georg Simmel (pp. 402-8). Glencoe, IL: The Free Press.

Skordaki, E. (1996). Glass Slippers and Glass Ceilings: Women in the Legal Profession. International Journal of the Legal Profession, 3(1-2), 7-43. https://doi.org/10.1080/09695958.1996.9960409

Smith Galer, S. (2017). How Metaphors Shape Women's Lives. Available at: https://www.bbc.com/future/article/20170718-the-metaphors-that-shape-womens-lives. (Accessed 21 April 2021).

Smith, P., Caputi, P. and Crittenden, N. (2012). A Maze of Metaphors Around Glass Ceilings. Gender in Management: An International Joumal 37(7), 436-448. https:// doi.org/10.1108/17542411211273432

Spender, D. (1980). Man Made Language. London: Routledge.

Stalker, J. (1994). Athene in Academe: Women Mentoring Women in the Academy. International Journal of Lifelong Education, 13(5), 361-372. https://doi.org/10.1080/0260137940130503

Still, L. V. (1986). Women in Management: The Case of Australian Business. Asia Pacific Journal of Human Resources, 24(1), 32-37. https://doi.org/10.1177/103841118602400108

Suspitsina, T. (2000). Mothers, Bosses, and Superwomen: The Construction of Identities of Russian Woman Administrators in Higher Education. Higher Education in Europe, 25(2), 207-212. https://doi.org/10.1080/713669245

Thompson, S. (1989). Motif-Index of Folk-Literature. Bloomington: Indiana University Press.

Thornton, M. (2013). The Mirage of Merit: Reconstituting the 'Ideal Academic'. Australian Feminist Studies, 28(76), 127-143. https://doi.org/10.1080/08164649.2013.789584

Tolmach-Lakoff, R. (1973). Language and Woman's Place. Language in Society, 2(1), 45-80. https://doi.org/10.1017/S0047404500000051

Trahar, S. (2019). Snow White, a Mirror and Whiteness: Entangling Thoughts in Metaphors, in S. Farquhar and E. Fitzpatrick (eds), Innovations in Narrative and Metaphor (pp. 149-165). Singapore: Springer. https://doi.org/10.1007/978-981-13-6114-2_10

Tripp-Knowles, P. (1995). A Review of the Literature on Barriers Encountered by Women in Science Academia. Resources for Feminist Research, 24(1/2), 28-34.

Turner, V. (1974). Dramas, Fields, and Metaphors: Symbolic action in buman society. Ithaca, NY: Cornell University Press.

Uther, H-J. (2004). The Types of International Folktales: A classification and bibliography, based on the system of Antti Aarne and Stith Thompson. Helsinki, Finland: Academia Scientiarum Fennica.

Van den Brink, M. and Benschop, Y. (2012a). Gender Practices in the Construction of Academic Excellence: Sheep with Five Legs. Organization, 19(4), 507-524. https://doi.org/10.1177/1350508411414293

Van den Brink, M. and Benschop, Y. (2012b). Slaying the Seven-Headed Dragon: The Quest for Gender Change in Academia. Gender, Work \& Organization, 19(1): 71-92. https://doi.org/10.1111/j.1468-0432.2011.00566.x

Williams, J. C. (2005). The Glass Ceiling and the Maternal Wall in Academia. New Directions for Higher Education, 130, 91-105. https://doi.org/10.1002/he.181

Woolf, V. (1998 [1929]). A Room of One's Own. Three Guineas. Oxford, UK: Oxford University Press. 
Yoder, J. D. (1991). Rethinking Tokenism: Looking Beyond Numbers. Gender \& Society, 5(2), 178-192. https://doi.org/10.1177/089124391005002003

Zinken J. and Musolff A. (2009). A Discourse-Centred Perspective on Metaphorical Meaning and Understanding, in A. Musolff and J. Zinken (eds) Metaphor and Discourse (pp.1-8). London: Palgrave Macmillan. https://doi.org/10.1057/9780230594647_1

Citation: Moratti, S. (2021). Contemporary Fairy Tales: Narrating Women Academics Through Metaphors. Feminist Encounters: A Journal of Critical Studies in Culture and Politics, 5(2), 21. https://doi.org/10.20897/femenc/11157

Copyright (C) 2021 by Author/s and Licensed by Lectito BV, Netherlands. This is an open access article distributed under the Creative Commons Attribution License which permits unrestricted use, distribution, and reproduction in any medium, provided the original work is properly cited. 